\title{
Complex Formation in a Liquid-Liquid Extraction System Containing Vanadium(IV/V), 2,3-Dihydroxynaphtahlene and Thiazolyl Blue
}

\author{
Galya K. Toncheva, ${ }^{1}$ Zlatimir T. Zhelev, ${ }^{1}$ Vassil B. Delchev ${ }^{1}$ \\ and Kiril B. Gavazov ${ }^{2, *}$ \\ ${ }^{1}$ Faculty of Chemistry, University of Plovdiv "Paisii Hilendarski”, Plovdiv 4000, Bulgaria \\ ${ }^{2}$ Faculty of Pharmacy, Medical University of Plovdiv, Plovdiv 4002, Bulgaria \\ *Corresponding author: E-mail: kgavazov@abv.bg
}

Received: 28-01-2018

\begin{abstract}
Liquid-liquid extraction systems for $\mathrm{V}^{\mathrm{IV} / \mathrm{V}}$ containing 2,3-dihydroxynaphtahlene (DN) and 3-(4,5-dimethylthiazol-2-yl)-2,5-diphenyl-2H-tetrazolium bromide (thiazolyl blue, MTT) were studied. The optimum conditions for $\mathrm{V}^{\mathrm{IV}}$ and $\mathrm{V}^{\mathrm{V}}$ extraction were found. $\mathrm{V}^{\mathrm{IV}}$ is extracted in chloroform as a 1:2:2 complex (V:DN:MTT) with $\lambda_{\max }=570 \mathrm{~nm}$ and $\varepsilon_{570}=2.9 \times 10^{4} \mathrm{dm}^{3} \mathrm{~mol}^{-1} \mathrm{~cm}^{-1}$. However, this wavelength was found unsuitable for precise spectrophotometric measurements due to time dependent absorbance changes. $\mathrm{V}^{\mathrm{V}}$ forms predominantly a 1:1:1 complex with $\lambda_{\max }=335 \mathrm{~nm}$. The calibration graph for this oxidation state is linear in the range of $0.06-1.5 \mu \mathrm{g} \mathrm{cm}^{-3}$. The molar absorptivity, Sandell's sensitivity and limit of detection were calculated to be $1.6 \times 10^{4} \mathrm{dm}^{3} \mathrm{~mol}^{-1} \mathrm{~cm}^{-1}, 3.2 \mathrm{ng} \mathrm{cm}{ }^{-2}$ and $0.02 \mu \mathrm{g} \mathrm{cm}$, respectively. The ground-state equilibrium geometries of the anionic parts of the extracted ion-associates, $\left[\mathrm{V}^{\mathrm{IV}} \mathrm{O}\left(\mathrm{DN}^{2-}\right)_{2}\right]^{2-}$ and $\left[\mathrm{V}^{\mathrm{V}} \mathrm{O}_{2}\left(\mathrm{DN}^{2-}\right)\right]^{-}$, were optimized at the BLYP/6-31++ $\mathrm{G}^{*}$ level of theory.
\end{abstract}

Keywords: Vanadium(IV/V); 2,3-dihydroxynaphtahlene; ternary complex; liquid-liquid extraction; spectrophotometry; DFT calculations

\section{Introduction}

Vanadium is an essential trace element for living organisms ${ }^{1}$ and a pillar of modern technology ${ }^{2}$ with a potentially significant environmental impact due to human activity, such as the burning of fossil fuels, manufacturing of steel alloys, dyes, glass and ceramics, and application as a catalyst in various processes. ${ }^{2,3}$ Vanadium is the fifth most abundant transition element in the Earth's crust with an average content of $0.014 \% .{ }^{3}$ Natural sources of airborne vanadium include continental dust, volcanic activity, marine aerosols and wild forest fires. ${ }^{2}$

It is known that prolong exposure to vanadium increases the risk of lung cancer and can damage the integumentary, respiratory, central nervous and digestive systems. ${ }^{4}$ The amount of vanadium resorbed in the gastrointestinal tract is a function of the oxidation state and coordination environment. ${ }^{5}$ The most important oxidation states of vanadium are IV and V. The ability to switch easily between them, along with the stereochemical flexibility of this element ${ }^{6}$ are key factors that determine its role in biological systems. ${ }^{1,7}$

Vanadium deficiency in animal species is related to stunted growth, impaired reproduction, altered red blood cell formation, disturbed iron metabolism and abnormalities in blood lipid levels. ${ }^{2,8}$ There is an opinion among health specialists that vanadium deficiency can affect humans in a similar way. ${ }^{2}$ Insufficiently studied issues concerning the balance between its toxicity and essentiality ${ }^{8,9}$ define the necessity for vanadium determination in various samples and call for investigations of coordination compounds, which have the potential to be used for $\mathrm{V}^{\mathrm{IV}}$ / $\mathrm{V}^{\mathrm{V}}$ speciation.

Many methods have been proposed for vanadium determination and speciation. ${ }^{10-13}$ Very sensitive and cost effective are the spectrophotometric methods based on ternary complexes with catechol type ligands. ${ }^{14-19}$ However, the mechanism of colour development in some of these methods ${ }^{14,15}$ is debatable because it is not clear whether 
the main spectral bands are due to the formation of coordination compounds or are products of reagent(s) oxidation and polymerization. ${ }^{20,21}$ On the other hand, it is difficult to find conditions for speciation analysis with such reagents as they are capable of reducing $\mathrm{V}^{\mathrm{V}}$ to $\mathrm{V}^{\mathrm{IV}} \cdot{ }^{19-26} \mathrm{In}$ fact, little is known about the stabilizing effects of additional reagents on the initial oxidation state of vanadium in ternary complexes of this kind.

Several papers ${ }^{27-30}$ describe liquid-liquid extraction (LLE) of $\mathrm{V}^{\mathrm{V}}$ with 2,3-dihydroxynaphthalene (DN), a ligand incorporating a catechol moiety, the interest in which has been revived thanks to Tarafder et al. ${ }^{31-33}$ In a previous paper, ${ }^{21}$ we compared the behaviour of $\mathrm{V}^{\mathrm{IV}}$ and $\mathrm{V}^{\mathrm{V}}$ in a LLE-chromogenic system involving DN and 2,3,5-triphenyl-2H-tetrazolium chloride (TTC). We found evidence for aggregation of the ternary complexes in the organic phase and shed light on the differences in the extraction mechanism for $\mathrm{V}^{\mathrm{IV}}$ and $\mathrm{V}^{\mathrm{V}}$.

Here, we report results for LLE-chromogenic systems containing $\mathrm{V}^{\mathrm{IV}}$ or $\mathrm{V}^{\mathrm{V}}, \mathrm{DN}$ and an alternative ion-association reagent: 3-(4,5-dimethylthiazol-2-yl)-2,5-diphenyl- $2 \mathrm{H}$-tetrazolium bromide (thiazolyl blue, MTT). MTT is a commercially available tetrazolium salt with many applications as a redox ${ }^{34}$ and ion-association reagent. ${ }^{35}$ MTT is known to have advantages over similar compounds in terms of stability and molar absorptivity of the obtained complexes ${ }^{35-38}$ and their applicability for $\mathrm{V}^{\mathrm{IV}} / \mathrm{V}^{\mathrm{V}}$ speciation analysis. ${ }^{26}$

\section{Experimental Procedure and Theoretical Details}

\section{1. Reagents and Apparatus}

Stock VIV aqueous solution $\left(\right.$ ca. $\left.5 \times 10^{-2} \mathrm{~mol} \mathrm{dm}^{-3}\right)$ was prepared from $\mathrm{VOSO}_{4} \cdot 5 \mathrm{H}_{2} \mathrm{O}$ (purum, Fluka AG, Switzerland) and standardized by potassium permanganate titration. Working solutions at a concentration of 2 $\times 10^{-4} \mathrm{~mol} \mathrm{dm}^{-3}$ and $\mathrm{pH} c a .3 .0$ were prepared daily by suitable dilution. $\mathrm{V}^{\mathrm{V}}$ solution $\left(2 \times 10^{-4} \mathrm{~mol} \mathrm{dm}^{-3}\right)$ was prepared by dissolving $\mathrm{NH}_{4} \mathrm{VO}_{3}$ (puriss. p.a., VEB Laborchemie Apolda, Germany) in water. Fresh DN chloroform solutions $\left(2 \times 10^{-3} \mathrm{~mol} \mathrm{dm}^{-3}\right)$ were prepared daily from the solid reagent (purum, Fluka AG, Switzerland). The concentration of MTT (p.a., LOBA Feinchemie GmbH, Austria) was $3 \times 10^{-3} \mathrm{~mol} \mathrm{dm}^{-3}$ (aqueous solution). The chloroform (p.a., Valerus, Bulgaria) was additionally distilled. The acidity of the aqueous medium was set by the addition of buffer solution, prepared by mixing $2.0 \mathrm{~mol}$ $\mathrm{dm}^{-3}$ aqueous solutions of $\mathrm{CH}_{3} \mathrm{COOH}$ and ammonia. $\mathrm{pH}$ was measured by a Hanna HI-83141 pH meter (Romania). Absorbance measurements were performed by using a Camspec M508 spectrophotometer (United Kingdom), equipped with $1 \mathrm{~cm}$ path-length glass cells. Distilled water was used throughout the work.

\section{2. Procedure}

Aliquots of $\mathrm{V}^{\mathrm{IV}}$ or $\mathrm{V}^{\mathrm{V}}$ solution, buffer solution (1 $\mathrm{cm}^{3}$ ) and MTT solution were placed into $125 \mathrm{~cm}^{3}$ separatory funnels. The volume was made to $10 \mathrm{~cm}^{3}$ with water. An aliquot of DN chloroform solution was added and the organic phase was made up to $10 \mathrm{~cm}^{3}$ with chloroform. The funnel was shaken for a fixed time period (10-240 s). After the separation of the phases, a portion of the organic extract was transferred through filter paper into the spectrophotometer cell. The absorbance was measured against chloroform or simultaneously prepared blank solution (containing all of the reagents with the exception of vanadium).

\section{3. Theoretical Details}

The structures of the anionic coordination compounds were optimized at the $\mathrm{BLYP} / 6-31++\mathrm{G}^{*}$ level of theory as described in the literature. ${ }^{21}$ The charge and multiplicity for $\left[\mathrm{V}^{\mathrm{IV}} \mathrm{O}\left(\mathrm{DN}^{2-}\right)_{2}\right]^{2-}$ were set to -2 and doublet, respectively. The theoretical calculations were performed with the GAUSSIAN 03 program package. The results were visualized with the ChemCraft program.

\section{Results and Discussion}

The following variables were considered for the performed LLE-spectrophotometric optimisation experiments: organic solvent, wavelength for spectrophotometric measurements, $\mathrm{pH}$, extraction time and concentration of the reagents.

\section{1. Choice of Organic Solvent and Spectral Characteristics}

Chloroform, ${ }^{21}$ dichloroethane, ${ }^{39}$ ethyl acetate ${ }^{29}$ and methyl isobutyl ketone ${ }^{30}$ were used in previous studies as extraction solvents for DN-containing complexes. Preliminary investigations showed that chloroform is the best solvent for the $\mathrm{V}^{\mathrm{IV} / \mathrm{V}}-\mathrm{DN}-\mathrm{MTT}$ species. Absorption spectra of these species are shown in Fig 1. Fig. 1a includes spectra obtained with a low DN concentration $\left(8.0 \times 10^{-5}\right.$ mol dm${ }^{-3}$ ). Significant differences can be observed for the two oxidation states. The $\mathrm{V}^{\mathrm{IV}}$ complex (spectrum 1) has two intensive maxima (at 330 and $560 \mathrm{~nm}$ ), while the $\mathrm{V}^{\mathrm{V}}$ complex (spectrum 2) is characterized by an intense maximum (at $335 \mathrm{~nm}$ ). Another maximum for this oxidation state is at $680 \mathrm{~nm}$; the corresponding band is broad and low intensive.

Spectra with a high DN concentration $\left(1.6 \times 10^{-3}\right.$ mol $\mathrm{dm}^{-3}$ ) are depicted in Fig. 1b. The spectral changes accompanying the increase of the DN concentration can be attributed to reduction of $\mathrm{V}^{\mathrm{V}}$ to $\mathrm{V}^{\mathrm{IV}}$. However, this reduction is only partial: there is no complete matching of the two spectra as observed under similar conditions in 
our previous studies ${ }^{21}$ for the couple $\mathrm{V}^{\mathrm{V}}-\mathrm{DN}-\mathrm{TTC}$ and $\mathrm{V}^{\mathrm{IV}}$-DN-TTC.

It should be mentioned that the absorbance of the blank is not stable in time (Fig. 1c). The increase of the ab-
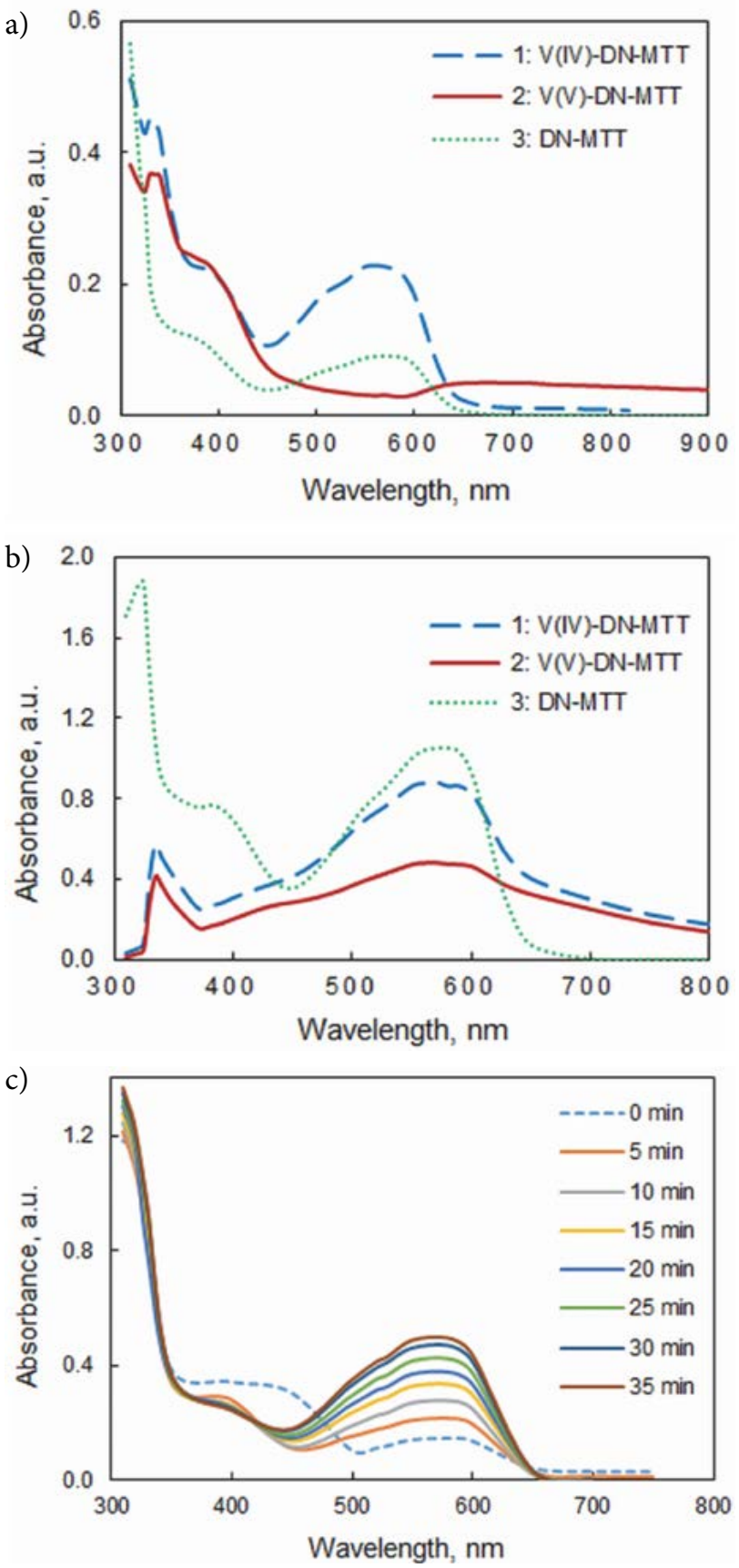

Figure 1. Absorption spectra in chloroform. a) At a low DN concentration, $8 \times 10^{-5} \mathrm{~mol} \mathrm{dm}^{-3}: 1-\mathrm{V}^{\mathrm{IV}}$-DN-MTT against blank; 2 $\mathrm{V}^{\mathrm{V}}$-DN-MTT against blank; 3 - blank (DN-MTT) against chloroform. $c_{\mathrm{V}(\mathrm{IV})}=c_{\mathrm{V}(\mathrm{V})}=3 \times 10^{-5} \mathrm{~mol} \mathrm{dm}^{-3}, c_{\mathrm{MTT}}=1.5 \times 10^{-4} \mathrm{~mol} \mathrm{dm}^{-3}$, $\mathrm{pH}$ 5, extraction time 2 min. b) At a high DN concentration, $1.6 \times$ $10^{-3} \mathrm{~mol} \mathrm{dm}^{-3}: 1-\mathrm{V}^{\mathrm{IV}}$-DN-MTT against blank; $2-\mathrm{V}^{\mathrm{V}}$-DN-MTT against blank; 3 - blank (DN-MTT) against chloroform. $c_{\mathrm{V}(\mathrm{IV})}=$ $c_{\mathrm{V}(\mathrm{V})}=3 \times 10^{-5} \mathrm{~mol} \mathrm{dm}^{-3}, c_{\mathrm{MTT}}=2.4 \times 10^{-4} \mathrm{~mol} \mathrm{dm}^{-3}, \mathrm{pH} 5$, extraction time 2 min. c) Influence of time on the spectrum of the blank: $c_{\mathrm{DN}}=4 \times 10^{-4} \mathrm{~mol} \mathrm{dm}^{-3}, c_{\mathrm{MTT}}=1.0 \times 10^{-4} \mathrm{~mol} \mathrm{dm}^{-3}, \mathrm{pH} \mathrm{5}$, extraction time $2 \mathrm{~min}$. sorbance at $580 \mathrm{~nm}$ fits well to a second order polynomial equation: $\mathrm{y}=-0.0001 x^{2}+0.0138 x+0.1477, R^{2}=0.9996$. The observed instability can be attributed to aggregation of the DN-MTT species in the organic phase. To eliminate this factor, in our further studies, we measured the absorbance at wavelengths outside the range of instability.

\section{2. Effect of $\mathrm{pH}$}

The effect of $\mathrm{pH}$ on the extraction is shown in Fig. 2. The absorbance of the $\mathrm{V}^{\mathrm{IV}}$ complex was measured at 335 (series 1) and $700 \mathrm{~nm}$ (series 1'). There are no significant differences in the $\mathrm{pH}$ profile for these wavelengths. This indicates that only one complex is extracted under the mentioned conditions (high DN concentration). Our further experiments were carried out at $\mathrm{pH}$ 5.0.

Series 2 represents the results for the complex obtained with $\mathrm{V}^{\mathrm{V}}$. The course of the obtained curve is different, especially for the $\mathrm{pH}$ region above 5.5 . This is in agreement with the concept that different complexes are formed with $\mathrm{V}^{\mathrm{IV}}$ and $\mathrm{V}^{\mathrm{V}}$ under the experimental conditions.

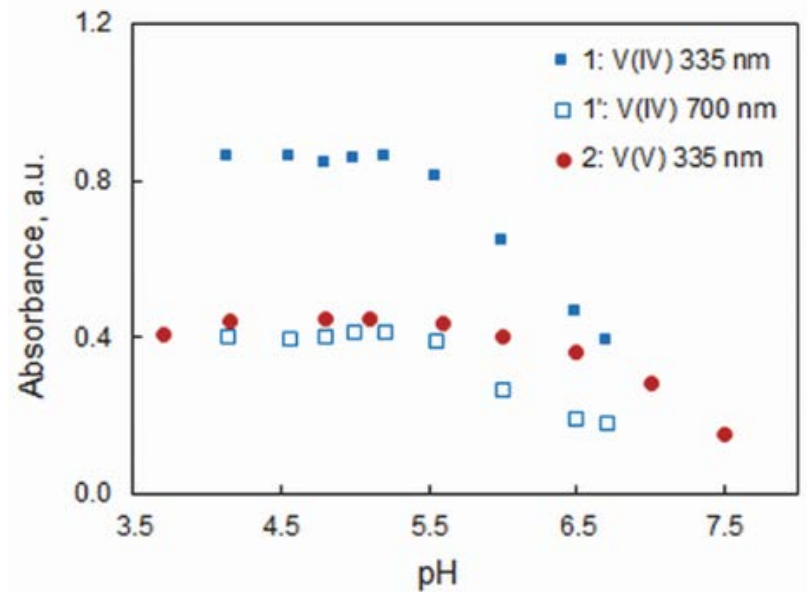

Figure 2. Absorbance of the $\mathrm{V}^{\mathrm{IV}}$ complex $\left(1\right.$ and $\left.1^{\prime}\right)$ and $\mathrm{V}^{\mathrm{V}}$ complex (2) vs $\mathrm{pH}$ of aqueous phase. $1,1^{\prime}-c_{\mathrm{V}(\mathrm{IV})}=4 \times 10^{-5} \mathrm{~mol} \mathrm{dm}^{-3}, c_{\mathrm{DN}}=$ $1.6 \times 10^{-3} \mathrm{~mol} \mathrm{dm}^{-3}, c_{\mathrm{MTT}}=1.0 \times 10^{-4} \mathrm{~mol} \mathrm{dm}^{-3}, \lambda=335 \mathrm{~nm}$ (1) or $700 \mathrm{~nm}\left(1^{\prime}\right) ; 2-c_{\mathrm{V}(\mathrm{V})}=3 \times 10^{-5} \mathrm{~mol} \mathrm{dm}^{-3}, c_{\mathrm{DN}}=6.0 \times 10^{-4} \mathrm{~mol} \mathrm{dm}^{-3}$, $c_{\mathrm{MTT}}=1.0 \times 10^{-4} \mathrm{~mol} \mathrm{dm}^{-3}, \lambda=335 \mathrm{~nm}$, extraction time $2 \mathrm{~min}$.

\section{3. Effect of Extraction Time}

The influence of extraction time on the absorbance was followed in the interval from 10 seconds to 4 minutes. The results show that the time of $1.5 \mathrm{~min}$ is sufficient for quantitative extraction. Extraction times longer than 2.5 min can lead to a slight decrease of the absorbance. Hence, we extracted for $2 \mathrm{~min}$ in the further experiments.

\section{4. Effect of DN Concentration}

The effect of DN concentration is shown in Fig. 3. Fig. $3 a$ represents the results for $\mathrm{V}^{\mathrm{V}}$. The absorbance at $335 \mathrm{~nm}$ is maximal when $c_{\mathrm{DN}} \geq 6 \times 10^{-4} \mathrm{~mol} \mathrm{dm}{ }^{-3}$. Fur- 
a)
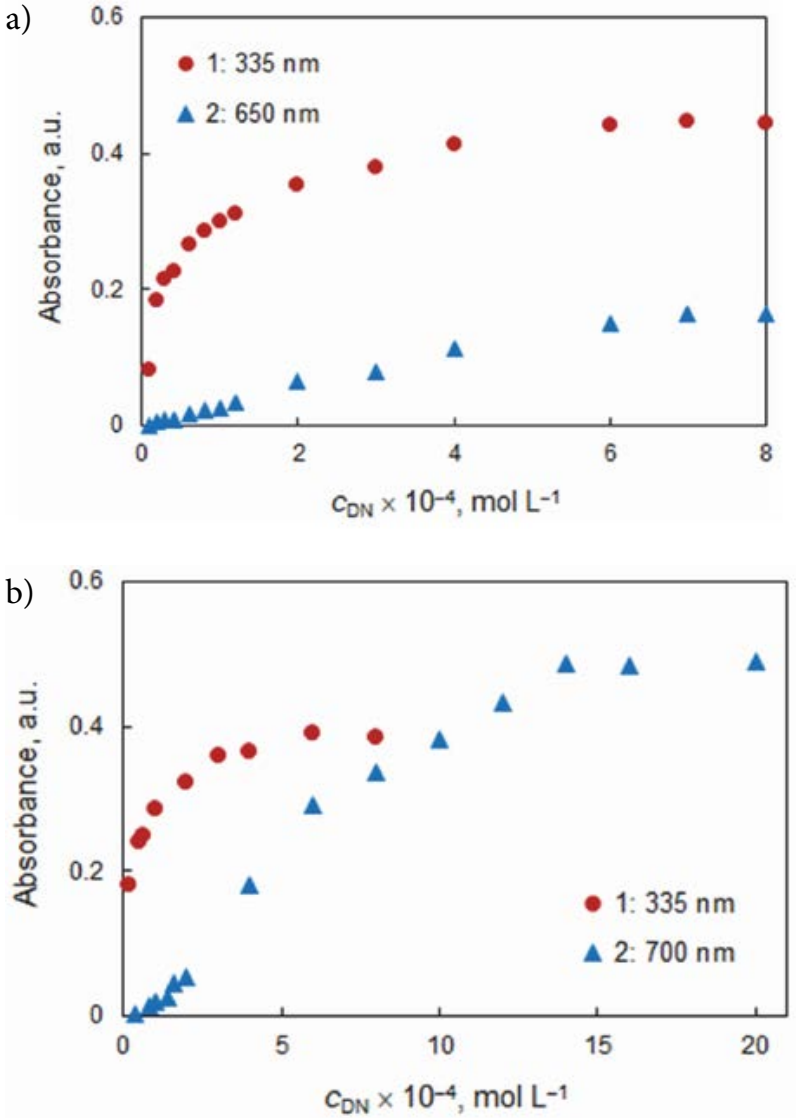

Figure 3. Absorbance of extracted complexes of $\mathrm{V}^{\mathrm{V}}$ (a) and $\mathrm{V}^{\mathrm{IV}}$ (b) vs DN concentration. a) $c_{\mathrm{V}(\mathrm{V})}=2 \times 10^{-5} \mathrm{~mol} \mathrm{dm}^{-3}, c_{\mathrm{MTT}}=1.5 \times 10^{-4}$ $\mathrm{mol} \mathrm{dm}{ }^{-3}$, pH 5.5, $\lambda=335 \mathrm{~nm}$ (1) and $650 \mathrm{~nm}$ (2). b) $c_{\mathrm{V}(\mathrm{IV})}=2 \times$ $10^{-5} \mathrm{~mol} \mathrm{dm}^{-3}(1)$ or $4 \times 10^{-5} \mathrm{~mol} \mathrm{dm}^{-3}(2) ; c_{\text {MTT }}=3.5 \times 10^{-4} \mathrm{~mol}$ $\mathrm{dm}^{-3}(1)$ or $1.0 \times 10^{-4} \mathrm{~mol} \mathrm{dm}^{-3}(2)$; pH 5.5 (1) or $5.0(2) ; \lambda=335$ $\mathrm{nm}(1)$ and $700 \mathrm{~nm}(2)$.

ther studies were performed at this DN concentration. Fig. $3 \mathrm{~b}$ shows the results for $\mathrm{V}^{\mathrm{IV}}$. It is noteworthy that the saturation at the two wavelengths (335 and $700 \mathrm{~nm}$ ) is achieved at different DN concentrations: $6 \times 10^{-4} \mathrm{~mol}$ $\mathrm{dm}^{-3}$ (for $335 \mathrm{~nm}$ ) and $1.4 \times 10^{-3} \mathrm{~mol} \mathrm{dm}^{-3}$ (for $700 \mathrm{~nm}$ ). This can be explained with the formation of different ternary complexes (see below): a 1:1 ( $\left.\mathrm{V}^{\mathrm{IV}}: \mathrm{DN}\right)$ complex with $\lambda_{\max }$ close to $335 \mathrm{~nm}$ and a $1: 2\left(\mathrm{~V}^{\mathrm{IV}}: \mathrm{DN}\right)$ complex with absorbance bands at higher wavelengths $\left(\lambda_{\max }=570 \mathrm{~nm}\right)$. Similar behaviour has been noticed in the $\mathrm{V}^{\mathrm{IV}}-\mathrm{DN}-\mathrm{TTC}$ system. $^{21}$

\section{5. Effect of MTT Concentration}

The effect of MTT concentration is shown in Fig. 4. Fig. 4a gives the results for $\mathrm{V}^{\mathrm{V}}$ at the optimum $\mathrm{DN}$ concentration $\left(6 \times 10^{-4} \mathrm{~mol} \mathrm{dm}^{-3}\right)$. The absorbance at $335 \mathrm{~nm}$ reach its maximal value for $c_{M T T} \geq 8 \times 10^{-5} \mathrm{~mol} \mathrm{dm}^{-3}$. Our further studies were performed at $c_{M T T}=1 \times 10^{-4} \mathrm{~mol}$ $\mathrm{dm}^{-3}$. The saturation curves for $\mathrm{V}^{\mathrm{IV}}$ are more complex (Fig. 4b). The absorbance steeply increases to about $c_{M T T}=$ $6 \times 10^{-5} \mathrm{~mol} \mathrm{dm}^{-3}$ and then decreases. A narrow plateau is
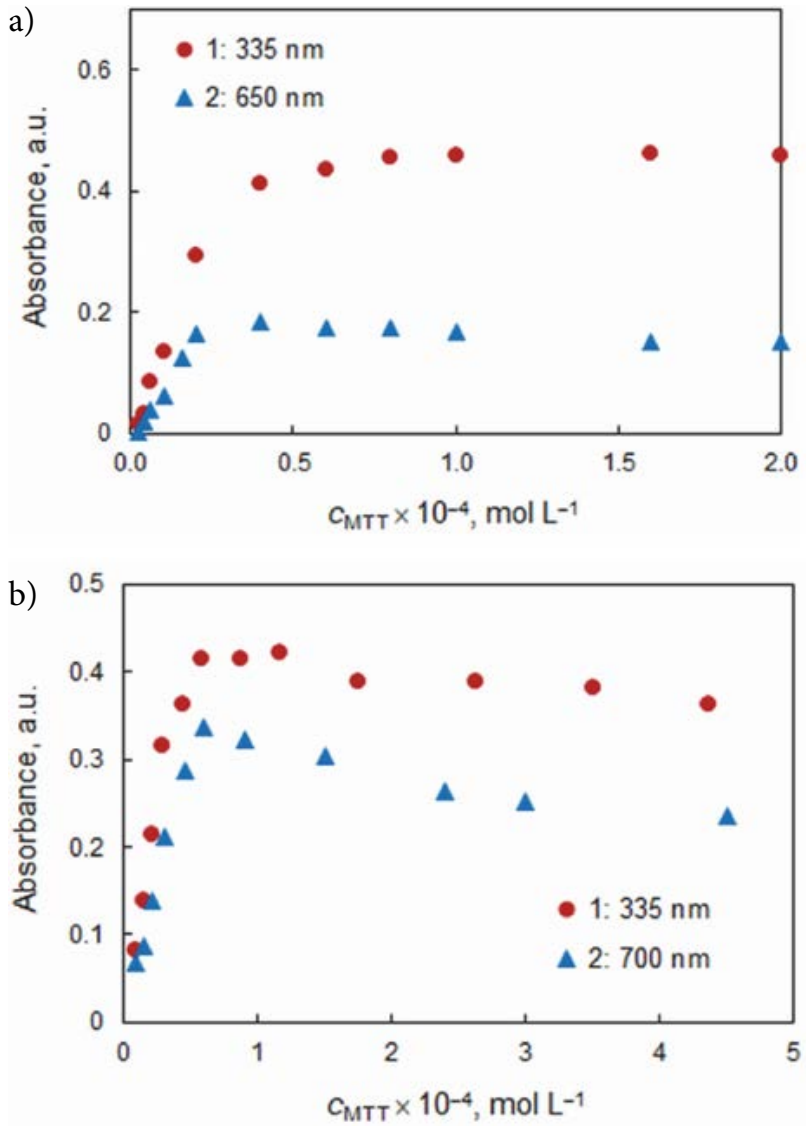

Figure 4. Absorbance of extracted complexes of $\mathrm{V}^{\mathrm{V}}$ (a) and $\mathrm{V}^{\mathrm{IV}}(\mathrm{b})$ vs MTT concentration. a) $c_{\mathrm{V}(\mathrm{V})}=3 \times 10^{-5} \mathrm{~mol} \mathrm{dm}^{-3}, c_{\mathrm{DN}}=6.0 \times$ $10^{-4} \mathrm{~mol} \mathrm{dm}^{-3}, \mathrm{pH} 5.5, \lambda=335 \mathrm{~nm}(1)$ and $650 \mathrm{~nm}(2)$. b) $c_{\mathrm{V}(\mathrm{IV})}=2$ $\times 10^{-5} \mathrm{~mol} \mathrm{dm}^{-3}(1)$ or $3 \times 10^{-5} \mathrm{~mol} \mathrm{dm}{ }^{-3}(2) ; c_{\mathrm{DN}}=4.0 \times 10^{-4} \mathrm{~mol}$ $\mathrm{dm}^{-3}(1)$ or $1.6 \times 10^{-3} \mathrm{~mol} \mathrm{dm}^{-3}(2) ; \mathrm{pH} 5.0 ; \lambda=335 \mathrm{~nm}$ (1) and 700 $\mathrm{nm}(2)$.

observed in the concentration range from $6 \times 10^{-5}$ to $1.2 \times$ $10^{-4} \mathrm{~mol} \mathrm{dm}^{-3}$ for $\lambda=335 \mathrm{~nm}$.

\subsection{Molar Ratios, Formulae and Equations}

To determine the $\mathrm{DN}$ : V molar ratios in the ternary complexes, we used two methods: the straight line method of Asmus ${ }^{40}$ and the mobile equilibrium method ${ }^{41}$ (Fig. 5). These methods give reliable results for relatively weak chemical bonds. ${ }^{42,43}$ The MTT : V molar ratios were determined by the Yoe \& Jones method ${ }^{44}$ (Fig. 6). The method is applicable for strong bonds, ${ }^{42,43}$ for which the two above-mentioned methods are usually inappropriate.

The results given in Fig. 5 (full markers; lines 1 and 1 ') show that there is a difference in the molar ratio for 335 $\mathrm{nm}\left(\mathrm{DN}: \mathrm{V}^{\mathrm{IV}}=1: 1\right)$ and $700 \mathrm{~nm}\left(\mathrm{DN}: \mathrm{V}^{\mathrm{IV}}=2: 1\right)$. Fig. $6 \mathrm{a}$, in its turn, shows that the molar MTT: $\mathrm{V}^{\mathrm{IV}}$ ratio is $2: 1$ independently of the wavelength. Therefore, the composition of the two ternary complexes is 1:1:2 ( $\mathrm{V}^{\mathrm{IV}}: \mathrm{DN}: \mathrm{MTT}$; low DN concentration) and 1:2:2 (optimum conditions).

The following equation can be proposed for $\mathrm{V}^{\mathrm{IV}}$ extraction under the optimum conditions (Table 1): 


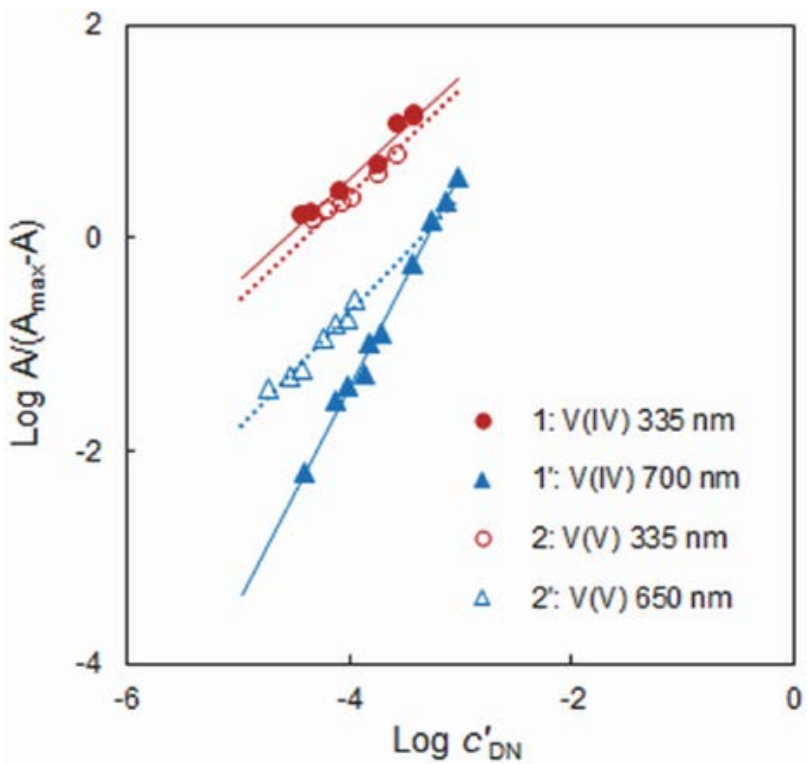

Figure 5. Determination of the $\mathrm{DN}: \mathrm{V}^{\mathrm{IV}}\left(1,1^{\prime}\right)$ and $\mathrm{DN}: \mathrm{V}^{\mathrm{V}}\left(2,2^{\prime}\right)$ molar ratios by the mobile equilibrium method at different wavelengths. Straight line equations: 1) $y=0.97 x+4.45$; 1') $y=2.01 x+$ 6.66; 2) $y=1.00 \mathrm{x}+4.41$; and 2') $y=1.09 \mathrm{x}+3.64$.

$$
\begin{aligned}
& \mathrm{VO}^{2+}(\mathrm{aq})+2 \mathrm{H}_{2} \mathrm{DN}(\mathrm{org})+2 \mathrm{MTT}^{+}(\mathrm{aq}) \\
& \rightleftharpoons\left(\mathrm{MTT}^{+}\right)_{2}\left[\mathrm{~V}^{\mathrm{IV}} \mathrm{O}\left(\mathrm{DN}^{2-}\right)_{2}\right](\mathrm{org})+4 \mathrm{H}^{+}(\mathrm{aq})
\end{aligned}
$$

The optimised ground-state geometry of the anionic chelate, $\left[\mathrm{V}^{\mathrm{IV}} \mathrm{O}\left(\mathrm{DN}^{2-}\right)_{2}\right]^{2-}$, is shown in Fig. 7, structure I. In contrast to the $\mathrm{V}^{\mathrm{IV}}$ complex with $\mathrm{DN}$ and $\mathrm{TTC}^{21}$ for which a 1:2:1 composition has been determined (the anionic chelate in it contains one doubly deprotonated and one singly deprotonated ligand, structure II), the two DN ligands in the present research are doubly deprotonated. As a result, the four $\mathrm{V}-\mathrm{O}$ bonds (with the oxygen atoms of $\mathrm{DN}$ ) have

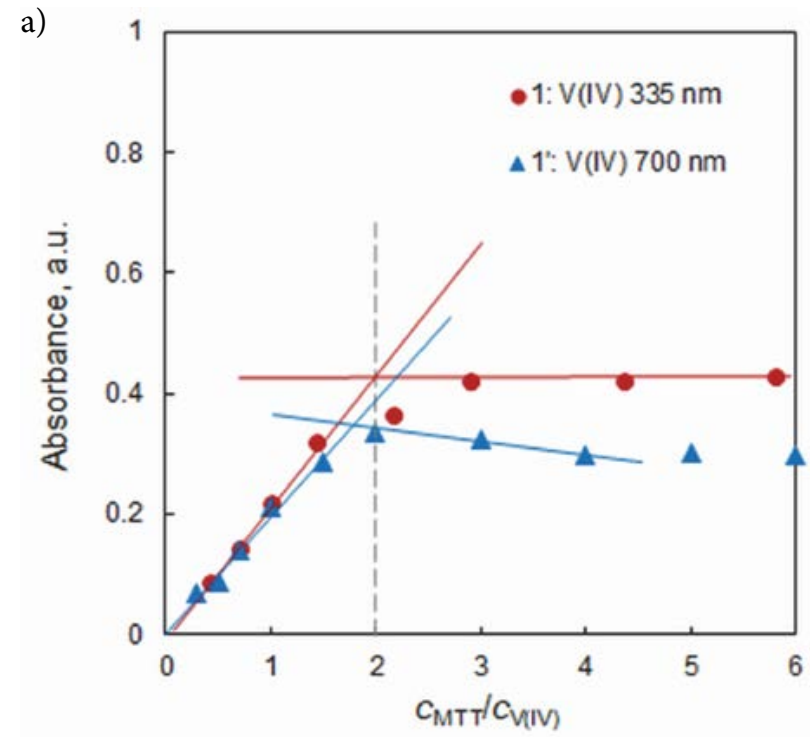

equal length $(2.020 \AA)$ and the structure is more stable. The dihedral angle between the two planar DN ligands is higher than that described in the literature. ${ }^{21}$ (Fig. 7, structure II) and the structure is not twisted: $\mathrm{C}_{19} \mathrm{O}_{24} \mathrm{~V}_{25} \mathrm{O}_{22}=$ $\mathrm{C}_{5} \mathrm{O}_{21} \mathrm{~V}_{25} \mathrm{O}_{23}=152.7^{\circ}$ and $\mathrm{C}_{4} \mathrm{O}_{22} \mathrm{~V}_{25} \mathrm{O}_{24}=\mathrm{C}_{18} \mathrm{O}_{23} \mathrm{~V}_{25} \mathrm{O}_{21}=$ $-152.7^{\circ}$. The corresponding angles for structure II are $144.0^{\circ}, 158.7^{\circ},-134.3^{\circ}$ and $-129.5^{\circ}$.

The composition of the ternary complex of $\mathrm{V}^{\mathrm{V}}$ is 1:1:1 (see Fig. 5, lines 2 and 2', and Fig. 6b). Its extraction can be expressed by equation 2 .

$$
\begin{aligned}
& \mathrm{H}_{2} \mathrm{VO}_{4}{ }^{-}(\mathrm{aq})+\mathrm{H}_{2} \mathrm{DN}(\mathrm{org})+\mathrm{MTT}^{+}(\mathrm{aq}) \\
& \rightleftharpoons\left(\mathrm{MTT}^{+}\right)\left[\mathrm{V}^{\mathrm{V}} \mathrm{O}_{2}(\mathrm{DN})\right](\mathrm{org})+2 \mathrm{H}_{2} \mathrm{O}(\mathrm{aq})
\end{aligned}
$$

Similar equation was proposed for the $\mathrm{V}^{\mathrm{V}}$-DN-TTC system. ${ }^{21}$ However, it was considered only as a first stage of a series of processes leading ultimately to the formation of a $\mathrm{V}^{\mathrm{IV}}$ complex. In contrast to $\left(\mathrm{TT}^{+}\right)\left[\mathrm{V}^{\mathrm{V}} \mathrm{O}_{2}(\mathrm{DN})\right],{ }^{21}\left(\mathrm{MTT}^{+}\right)$ $\left[\mathrm{V}^{\mathrm{V}} \mathrm{O}_{2}(\mathrm{DN})\right]$ is a stable ion-pair, less susceptible to oxidation-reduction events. Hence, MTT plays a stabilizing role on $\mathrm{V}^{\mathrm{V}}$ in a higher degree than TTC.

The optimised ground-state geometry of $\left[\mathrm{VO}_{2}(\mathrm{DN})\right]^{2-}$ is shown in Fig. 7, structure III. The complex is tetrahedral with distances $\mathrm{V}_{14}-\mathrm{O}_{11}=\mathrm{V}_{14}-\mathrm{O}_{12}=1.927$,

\begin{tabular}{|c|c|c|c|}
\hline \multirow[t]{2}{*}{ Parameter } & \multicolumn{2}{|c|}{ Optimal value/range } & \multirow{2}{*}{ Figure } \\
\hline & & & \\
\hline $\mathrm{pH}$ & $5.0-5.2$ & $4.8-5.5$ & Fig. 2 \\
\hline Concentration of DN, $\mathrm{mol} \mathrm{L}^{-1}$ & $1.6 \times 10^{-3}$ & $6 \times 10^{-4}$ & Fig. 3 \\
\hline Concentration of MTT, mol L-1 & $1.2 \times 10^{-4}$ & $1 \times 10^{-4}$ & Fig. 4 \\
\hline Extraction time, $s$ & 120 & 120 & - \\
\hline
\end{tabular}
$\mathrm{V}_{14}-\mathrm{O}_{13}=1.636$ and $\mathrm{V}_{14}-\mathrm{O}_{15}=1.641$.

Table 1. Optimum conditions for extraction of the ternary complexes

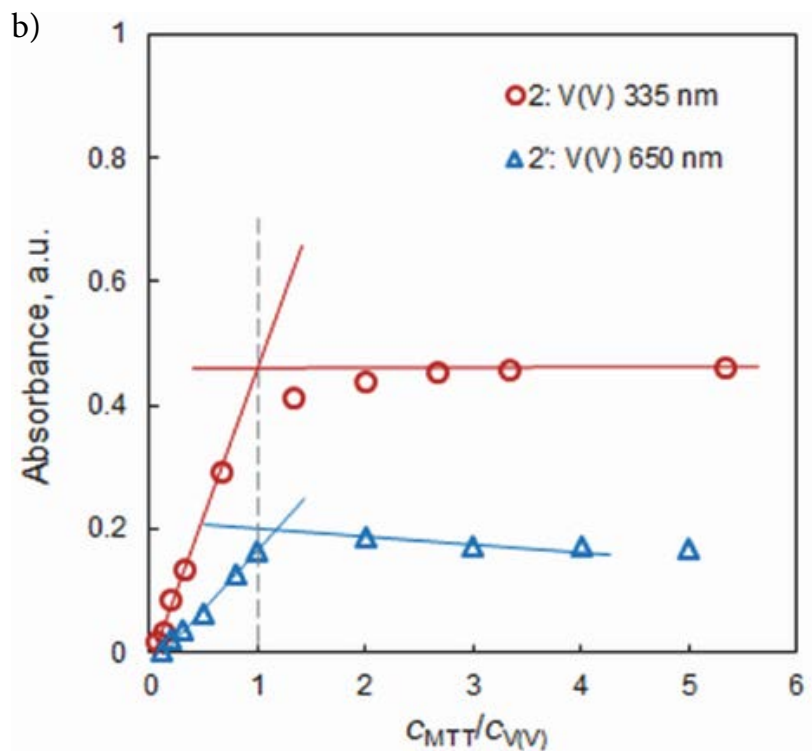

Figure 6. Determination of the $\mathrm{MTT}_{\mathrm{V}} \mathrm{VIV}^{\mathrm{IV}}$ (a) and $\mathrm{MTT}: \mathrm{V}^{\mathrm{V}}(\mathbf{b})$ molar ratios by the Yoe \& Jones method. 


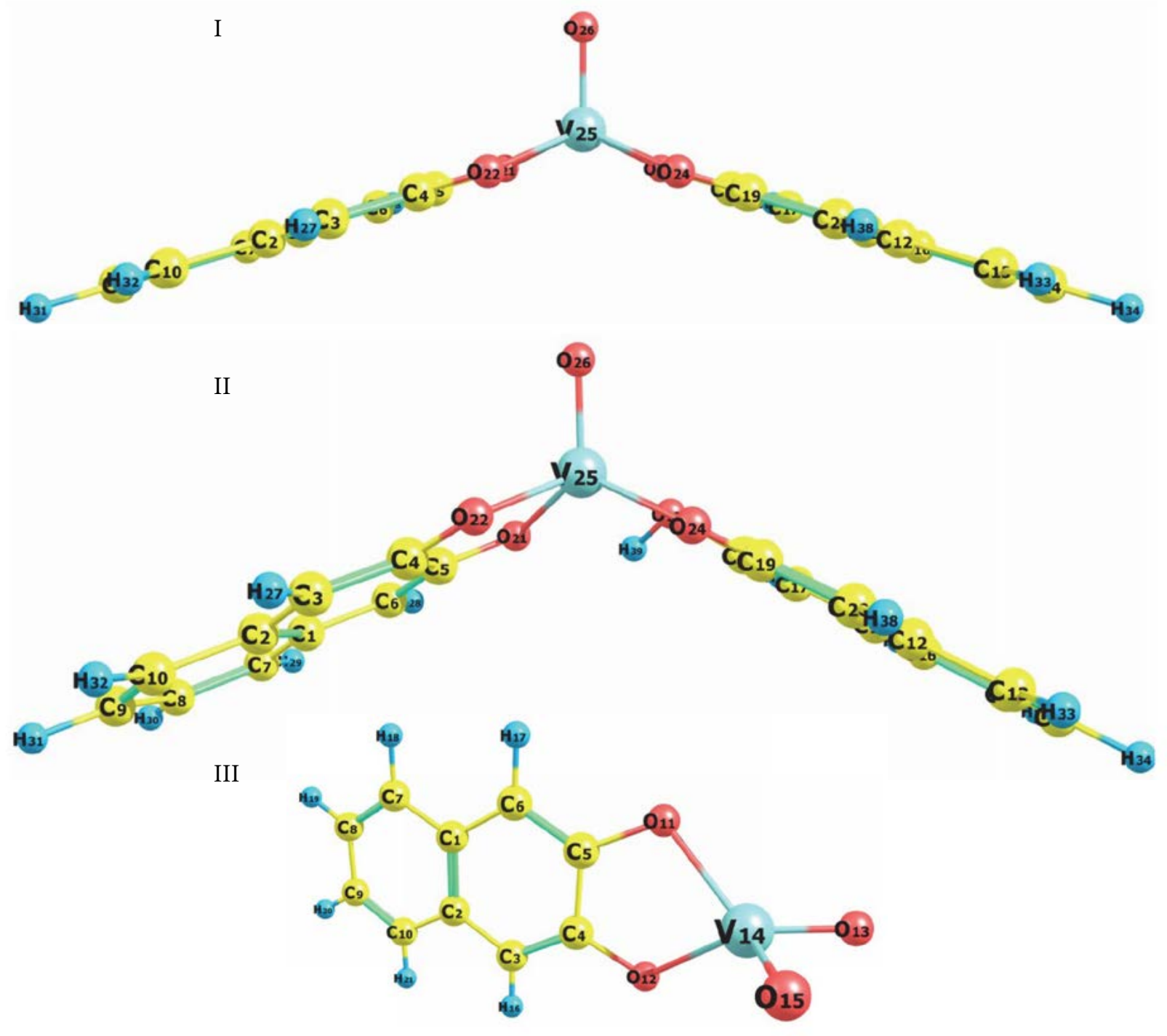

Figure 7. The optimized ground-state geometry of $\left[\mathrm{V}^{\mathrm{IV}} \mathrm{O}\left(\mathrm{DN}^{2-}\right)_{2}\right]^{2-}(\mathrm{I}),\left[\mathrm{V}^{\mathrm{IV}} \mathrm{O}\left(\mathrm{DN}^{2-}\right)(\mathrm{DNH})^{-}\right]^{-}(\mathrm{II})^{21}$ and $\left[\mathrm{V}^{\mathrm{V}} \mathrm{O}_{2}\left(\mathrm{DN}^{2-}\right)\right]^{-}(\mathrm{III}) .^{21}$

\section{7. Analytical Characteristics}

Under the optimum conditions (Table 1), $\mathrm{V}^{\mathrm{IV}}$ is extracted as an ion-association complex, $\left(\mathrm{MTT}^{+}\right)_{2}$ $\left[\mathrm{VO}\left(\mathrm{DN}^{2-}\right)_{2}\right]$. Its molar absorptivity at $\lambda_{\max }\left(\varepsilon_{570}=2.9 \times\right.$ $10^{4} \mathrm{dm}^{3} \mathrm{~mol}^{-1} \mathrm{~cm}^{-1}$; Fig. 1b), calculated from the absorbance measured immediately after the extraction, is higher than the molar absorptivities of similar complexes (Table 2 ). However, this wavelength was found unsuitable for precise spectrophotometric measurements due to the above-mentioned instability of the absorbance (Fig. 1c). Because of the relatively high DN concentration, the results for the second maximum $\left(\lambda=335 \mathrm{~nm} ; \varepsilon_{335}=1.9 \times 10^{4}\right.$ $\mathrm{dm}^{3} \mathrm{~mol}^{-1} \mathrm{~cm}^{-1}$ ) were also not satisfactory (high absorbance of the blank; insufficient repeatability).

By comparing the conditions for $\mathrm{V}^{\mathrm{IV}}$ and $\mathrm{V}^{\mathrm{V}}$ (Table $1)$, it is noticeable that lower reagents concentrations are needed for quantitative extraction of $\mathrm{V}^{\mathrm{V}}$. It was found that the results are repeatable and the dependence between the absorbance at $\lambda_{\max }=335 \mathrm{~nm}$ and concentration of $\mathrm{V}^{\mathrm{V}}$ is linear $\left(R^{2}=0.9994, N=10\right)$ in a wide range $(0.06-1.5 \mu \mathrm{g}$ $\left.\mathrm{cm}^{-3}\right)$. The regression equation was $A=0.316 \gamma-0.0002$. The standard deviations of the slope and intercept were 0.003 and 0.002 , respectively. The limits of detection (LOD) and quantitation (LOQ) calculated as 3 and 10 times SD of the intercept divided by the slope were $0.02 \mu \mathrm{g} \mathrm{cm}^{-3}$ and $0.06 \mu \mathrm{g} \mathrm{cm}^{-3}$. The molar absorptivity and Sandell's sensitivity were $1.6 \times 10^{4} \mathrm{dm}^{3} \mathrm{~mol}^{-1} \mathrm{~cm}^{-1}$ and $3.2 \mathrm{ng} \mathrm{cm}^{-2}$.

\section{Conclusions}

Vanadium(IV) and vanadium(V) form different chloroform-extractable ternary complexes with $\mathrm{DN}$ and MTT. Under the optimum conditions, $\mathrm{V}^{\mathrm{IV}}$ is extracted as a 1:2:2 complex (V:DN:MTT) with $\lambda_{\max }=570 \mathrm{~nm}$. $\mathrm{V}^{\mathrm{V}}$, in its turn, forms a 1:1:1 complex with $\lambda_{\max }=335 \mathrm{~nm}$. This com- 
Table 2. Influence of the cationic ion-association reagent on the complex's characteristics

\begin{tabular}{|c|c|c|c|c|c|}
\hline Complex $^{\star}$ & Composition & Organic solvent & $\lambda_{\max }, \mathbf{n m}$ & $\varepsilon_{\max }, \mathrm{dm}^{3} \mathrm{~mol}^{-1} \mathrm{~cm}^{-1}$ & Ref. \\
\hline $\mathrm{V}^{\mathrm{V}}$-DN & $1: 2$ & MIBK & 530 & $1.5 \times 10^{4}$ & 30 \\
\hline $\mathrm{V}^{\mathrm{V}}-\mathrm{DN}-\mathrm{CTAB}$ & Not studied & ethylacetate & 530 & $1.5 \times 10^{4}$ & 29 \\
\hline $\mathrm{V}^{\mathrm{V}}-\mathrm{DN}-\mathrm{TV}$ & $1: 2: 1$ & chloroform & 342 & $1.5 \times 10^{4}$ & 28 \\
\hline $\mathrm{V}^{\mathrm{V}}$-DN-INT & $1: 2: 1$ & chloroform & 340 & $2.5 \times 10^{4}$ & 27 \\
\hline $\mathrm{V}^{\mathrm{IV}}$-DN-TTC & $1: 2: 1$ & chloroform & 333 & $2.1 \times 10^{4}$ & 21 \\
\hline $\mathrm{V}^{\mathrm{V}}-\mathrm{DN}-\mathrm{MTT}$ & $1: 1: 1$ & chloroform & 335 & $1.6 \times 10^{4}$ & This work \\
\hline $\mathrm{V}^{\mathrm{IV}}$-DN-MTT & $1: 2: 2$ & chloroform & 570 & $2.9 \times 10^{4}$ & This work \\
\hline
\end{tabular}

* - The initial oxidation state of vanadium is given

Abbreviations: $\mathrm{CTAB}$, cetyltrimethylammonium bromide; TV, tetrazolium violet; INT, iodonitrotetrazolim chloride; TTC, triphenyltetrazolium chloride

plex is obtained under mild conditions (low concentration of the reagents and wide $\mathrm{pH}$ range) and can be used for spectrophotometric determination of vanadium. When the DN concentration is not very high, the well-documented in the literature $\mathrm{V}^{\mathrm{V}} \rightarrow \mathrm{V}^{\mathrm{IV}}$ reduction by DN (a catecholic type ligand) is not observed. This fact can be a starting point for future research on the development of a method for spectrophotometric determination of $\mathrm{V}^{\mathrm{V}}$ and $\mathrm{V}^{\mathrm{IV}}$ in their co-presence.

\section{References}

1. H. E. Michibata, Vanadium: biochemical and molecular biological approaches. Springer, Dordrecht-Heidelberg-London-New York, 2012. DOI:10.1007/978-94-007-0913-3

2. B. Gummow, in: J. O. Nriagu, (Ed.): Encyclopedia of Environmental Health, Elsevier, Burlington, 2011; pp. 628-636.

DOI:10.1016/B978-0-444-52272-6.00661-

3. K. K. Chatterjee, Uses of Metals and Metallic Minerals, New Age International (P) Ltd. Publishers, New Delhi, India, 2007, pp. 272-275.

4. A. Padilla-Rodríguez, J. A. Hernández-Viezcas, J. R. Peralta-Videa, J. L. Gardea-Torresdey, O. Perales-Pérez, F. R. Román-Velázquez, Microchem. J. 2015, 118, 1-11.

DOI: $10.1016 /$ j.microc.2014.07.011

5. Rehder, D., in: A. Sigel, H. Sigel, R. K.O. Sigel (Eds.): Interrelations between Essential Metal Ions and Human Diseases, Springer, 2013, pp. 139-169.

DOI: $10.1007 / 978-94-007-7500-8$

6. V. Ugone, E. Garribba, G. Micera, D. Sanna, J. Chem. Educ. 2015, 92, 1098-1102. DOI: 10.1021/ed500794m

7. D. Rehder, Metallomics 2015, 7, 730-742.

DOI: $10.1039 / \mathrm{C} 4 \mathrm{MT} 00304 \mathrm{G}$

8. K. Gruzewska, A. Michno, T. Pawelczyk, H. Bielarczyk, J. Physiol. Pharmacol. 2014, 65, 603-611.

9. Ghosh, R.; Banik, S., in: D. Bagchi, A. Swaroop (Eds.): Food Toxicology, CRC Press, Boca Raton, 2017, pp. 337-354.

10. M. J. C. Taylor, J. F. Staden, Analyst 1994, 119, 1263-1276. DOI: $10.1039 /$ AN9941901263

11. Z. L. Chen, G. Owens, Anal. Chim. Acta 2008, 607, 1-14. DOI: $10.1016 /$ j.aca.2007.11.013
12. K. Pyrzyńska, Microchim. Acta 2005, 149, 159-164. DOI: $10.1007 / \mathrm{s} 00604-004-0304-5$

13. W.-Y. He, K.-P. Wang, J.-Y. Yang, Toxicol. Environ. Chem. 2018, DOI: $10.1080 / 02772248.2018 .1428325$

14. C. Agarwal, M. Deb, R. Mishra, Anal. Lett. 1990, 23, $2063-$ 2075. DOI: $10.1080 / 00032719008052550$

15. C. Agrawal, K. S. Patel, R. K. Mishra, Bull. Chem. Soc. Jpn. 1991, 64, 2616-2618. DOI: 10.1246/bcsj.64.2616

16. T. Prasada Rao, M. L. P. Reddy, A. R. Pillai, Talanta 1998, 46, 765-813. DOI: 10.1016/S0039-9140(97)00262-2

17. Z. Marczenko, M. Balcerzak, Metod'y spektrofotometrii v UF i vidimoj oblastyakh $v$ neorganicheskom analize (in Russian), Binom. Laboratoriya znanij, Moscow, 2007.

18. Gavazov, K. B., Acta Chim. Slov. 2012, 59, 1-17.

19. N. K. Temel, R. Gürkan, Acta Chim. Slov. 2018, 65, 138-149. DOI:10.17344/acsi.2017.3724

20. A. M. Nardillo, J. A. Catoggio, Anal. Chim. Acta 1975, 74, 85-99. DOI: 10.1016/S0003-2670(01)82782-3

21. K. B. Gavazov, G. K. Toncheva, V. B. Delchev, Open Chem. 2016, 14, 197-205. DOI: 10.1515/chem-2016-0022

22. K. Kustin, S.-T. Liu, C. Nicolini, D. Toppen, J. Am. Chem. Soc. 1974, 96, 7410-7415. DOI: 10.1021/ja00831a600

23. J. H. Ferguson, K. Kustin, Inorg. Chem. 1979, 18, 3349-3357. DOI: $10.1021 /$ ic50202a015

24. K. Gavazov, Z. Simeonova, A. Alexandrov, Russ. J. Inorg. Chem. 2001, 46, 427-431.

25. S. Adediran, R. Pratt, Biochemistry 2008, 47, 9467-9474. DOI: $10.1021 /$ bi801153j

26. P. Racheva, K. Gavazov, V. Lekova, A. Dimitrov, J. Iran. Chem. Res. 2008, 1, 113-121.

27. Z. Simeonova, K. Gavazov, A. Alexandrov, Cent. Eur. J. Chem. 2006, 4, 258-266. DOI: 10.2478/s11532-006-0011-7

28. V. Lekova, K. Gavazov, A. Dimitrov, P. Racheva, Sci. Res. Union Sci. Plovdiv, Ser. C 2007, 6, 171-174.

29. R. K. Mondal, D. P. S. Rathore, P. K. Tarafder, in: National Seminar on Significant Advancements in Plasma/Flame/Associated Techniques and their Applications in Chemical Characterization of Atomic Minerals (SAP-2013), AMD Hyderabad, India, January 23-24 2013: AMD Hyderabad, India, pp. $83-84$.

30. R. K. Mondal, D. P. S. Rathore, P. K. Tarafder, Explor. Res. Atomic Miner. 2013, 23, 113-116. 
31. P. K. Tarafder, R. K. Mondal, Rev. Anal. Chem. 2011, 30, 7381. DOI: $10.1515 /$ REVAC.2011.016

32. P. K. Tarafder, S. K. Pradhan, R. K. Mondal, J. Radioanal. Nucl. Chem. 2016, 309, 1021-1028.

DOI: $10.1007 /$ s10967-016-4738-0

33. P. K. Tarafder, P. K. Ghosh, S. K. Pradhan, J. Radioanal. Nucl. Chem. 2017, 313, 353-360.

DOI: $10.1007 / \mathrm{s} 10967-017-5334-7$

34. R. W. Sabnis, Handbook of biological dyes and stains: synthesis and industrial applications, Wiley, Hoboken, US, 2010, pp. 485-487. DOI:10.1002/9780470586242

35. K. B. Gavazov, A. N. Dimitrov, V. D. Lekova, Russ. Chem. Rev. 2007, 76, 169-179.

DOI: $10.1070 / \mathrm{RC} 2007 \mathrm{v} 076 \mathrm{n} 02 \mathrm{ABEH} 003655$

36. K. B. Gavazov, V. D. Lekova, G. I. Patronov, Acta Chim. Slov. 2006, 53, 506-511.
37. P. V. Racheva, K. B. Gavazov, V. D. Lekova, A. N. Dimitrov, J. Anal. Chem. 2010, 65, 21-25.

DOI: $10.1134 / \mathrm{S} 1061934810010053$

38. G. K. Toncheva, T. S. Stefanova, K. B. Gavazov, Oriental J. Chem. 2015, 31, 327-332. DOI: 10.13005/ojc/310137

39. S. Kostova, V. Stajkovska, A. Aleksandrov, Sci. Works Plovdiv Univ. Chem. 2000, 29, 9-14.

40. E. Asmus, Fresenius' J. Anal. Chem. 1960, 178, 104-116. DOI: $10.1007 /$ bf00467200

41. Z. Zhiming, M. Dongsten, Y. Cunxiao, J. Rare Earths 1997, 15, 216-219.

42. M. I. Bulatov, I. P. Kalinkin, Prakticheskoe rukovodstvo po fotokolorimetricheskim i spektrofotometricheskim metodam analiza (in Russian), Khimiya, Leningrad, 1986.

43. K. B. Gavazov, Chemistry 2013, 22, 222-253.

44. J. H. Yoe, A. L. Jones, Ind. Eng. Chem. Anal. Ed. 1944, 16, 111-115. DOI: $10.1021 / \mathrm{i} 560126 \mathrm{a} 015$

\section{Povzetek}

Proučili smo ekstrakcijski sistem tekočina-tekočina za $\mathrm{V}^{\mathrm{IV} / \mathrm{V}}$, ki vsebuje 2,3-dihidroksinaftalen (DN) in 3-(4,5-dimetiltiazol-2-il)-2,5-difenil-2H-tetrazolijev bromid (tiazolil modro, MTT). Določili smo optimalne pogoje za ekstrakcijo $\mathrm{V}^{\mathrm{IV}}$ in $\mathrm{V}^{\mathrm{V}}$. VIV smo ekstrahirali v kloroformu kot 1:2:2 kompleks (V:DN:MTT) $\mathrm{z} \lambda_{\max }=570 \mathrm{~nm}$ in $\varepsilon_{570}=2.9 \times 10^{4} \mathrm{dm}^{3} \mathrm{~mol}^{-1} \mathrm{~cm}^{-1}$, vendar ta valovna dolžina ni primerna za natančne spektrofotometrične meritve zaradi časovno odvisne spremembe absorbance. $\mathrm{V}^{\mathrm{V}}$ tvori predvsem 1:1:1 kompleks $\mathrm{z} \lambda_{\max }=335 \mathrm{~nm}$. Za to oksidacijsko stanje je umeritvena krivulja linearna v območju 0.06-1.5 $\mu \mathrm{g} \mathrm{cm}^{-3}$. Vrednosti za molsko absorptivnost, Sandellovo občutljivost in mejo detekcije so $1.6 \times 10^{4}$ $\mathrm{dm}^{3} \mathrm{~mol}^{-1} \mathrm{~cm}^{-1}, 3.2 \mathrm{ng} \mathrm{cm}^{-2}$ in $0.02 \mu \mathrm{g} \mathrm{cm}^{-3}$. Osnovno stanje struktur anionov prisotnih v ravnotežju, $\left[\mathrm{V}^{\mathrm{IV}} \mathrm{O}\left(\mathrm{DN}^{2-}\right)_{2}\right]^{2-}$ in $\left[\mathrm{V}^{\mathrm{V}} \mathrm{O}_{2}\left(\mathrm{DN}^{2-}\right)\right]^{-}$, smo optimizirali na BLYP/6-31++ $\mathrm{G}^{*}$ nivoju teorije. 